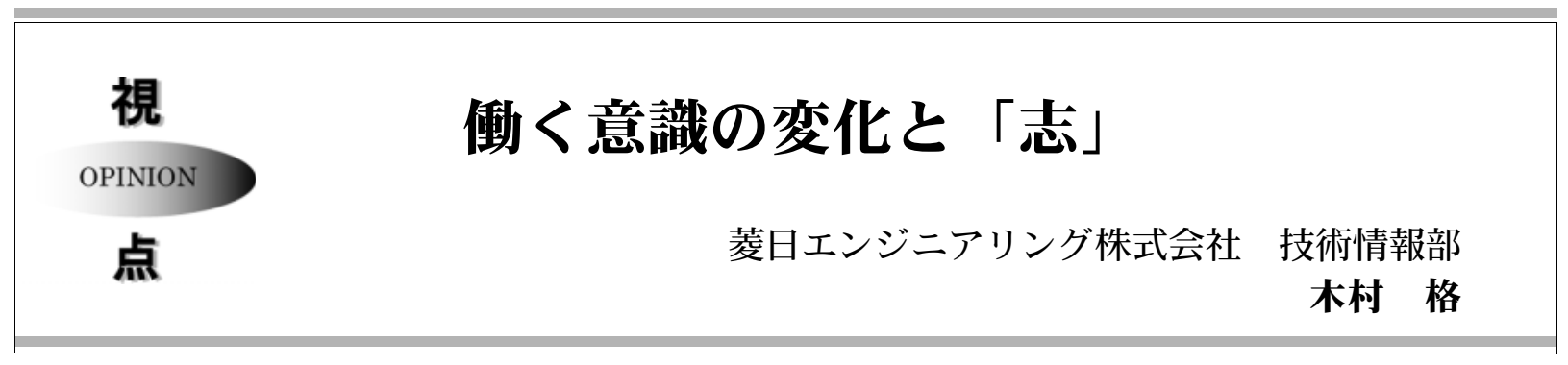

企業の中で働く人たちの意識も 21 世紀に入り労働 人口の構成の変化, 社会環境の変化の中で変わりつ つあるが, 最近気になっている言葉が「志」という 言葉である。

\section{1. 情報管理の現場では}

私の所属する情報センターにおいても，設立時は 成長期最後のバブルの時期であり, 主な業務は社外 情報の図書 - 雑誌や文献類の収集, 登録管理, 提供 サービス, そして急激に伸びていた社外DBの情報検 索サービスが主であった。そして今, 企業内図書館 としては蔵書の保存管理という「物」の管理から， 「物を含めた情報」である広い範囲の情報管理へと急 激に変化してきている。企業内においても, ネット ワーク環境を活用したパソコンでの業務が当たり前 の状況の中, 当然, 企業内図書館もバーチャル化の 方向にあり, 図書の貸し出し, 情報検索依頼はネッ ト上でのやり取りになり, 情報の共有化もどんどん 進んできている。そういう意味で, 情報管理業務は 管理面優先の時代から, 情報活用の時代に入ってい る。このような背景の中, 情報管理の専門家として は, 従来の図書館での蔵書の分類保存管理体系に強 い「司書」, 社外データベースの達人「サーチャー」 に加えて, 近年は, Web情報を通じた世界の企業情 報・統計的情報・各国政府動向などの情報に強い 「Web情報の達人」, そして, 得られた情報を整理す るための「データ整理の達人」といった幅広いスキ ルが要求されてきている。

また, 最近では自社やグループ会社自身の企業内 情報を扱うことも, 情報センターの業務の一部とな りつつある。10年前はOA技術ということで文書作成 と表計算のOA技術があれば済んだ時代であった。し かし, あっと言う間に急速なIT技術が進化し, 情報 管理の現場でもネットワークを利用した情報共有 · 発信や社内データベース構築, 活用など非常に広範

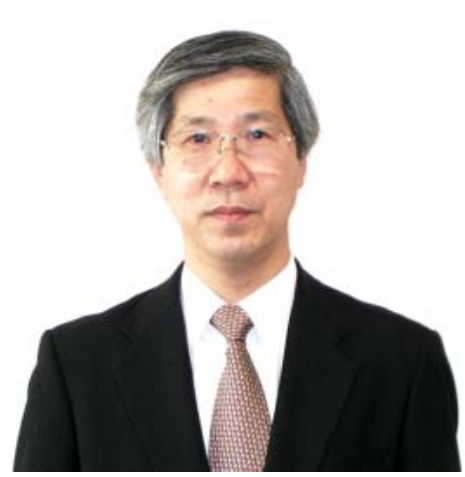

囲のスキルが要求されてきているのが現状である。

しかし, 現実には急激な変化に対応できる企業内 組織は非常に少ないのではないかと思われる。まず, 業務に習熟した人がIT関連技術を身に付けて業務を こなすのか, IT関連技術を有している人が業務を勉 強して業務をこなすのか, という問題がある。少な くとも従来は, $\mathrm{SE}$ (システムエンジニア) が業務シ ステムを開発してきたが, 情報管理の現場ではそれ ほど成功した例は見られず, さまざまなシステムが 出ては消えの連続ではなかったかと思う。これから の企業の情報管理の現場は, 情報活用を考えての新 しい時代に本当に必要なことは何か, そして, その 担い手である我々はいかに対応したらいいのだろう か，ということを根本から考える時期に来ている。

\section{2. 働き手の意識の変化}

最近, もうひとつ, 働き手側の意識にも変化が出 てきた。戦後 60 年,そして 21 世紀に入って 5 年がたち, 戦後復興経済の中で, 国を挙げての経済成長路線が 終わり, 追いつき, 追い越せの時代ではなくなった。 そして, 新聞・雑誌等のマスコミでは, 定年期を迎 える我々団塊の世代（1947～1949年生まれ）に関す る話題が多い。この世代が社会に出た時は男性主体 の社会であり, 結婚すると核家族の「ニューファミ リー」と言われ, 女性は専業主婦化が進み, 男性は 
企業の発展とともに企業戦士として過ごし，仕事優 先で会社人間として働いてきたのが一般的であった。 私自身も1947年生まれの団塊の世代である。私自身 には企業戦士であるという意識はもともとないが,こ こ2 3年, 明らかに自分の意識に変化がある。物的 な所有欲は確かに減少し, 逆に, 心豊かに生活する ことへの価值が大切な要素となってきている。たく さんの物を持つよりは, 本当に気に入った物をほど ほどに持ち, シンプルな生活を大切にして行きたい 気持ちが増している。また, 自分達のノウハウにつ いて次世代へいかにバトンを引き継いでいくかとい う，人材をいかに育てるかに関する意識も増してい る。

高度成長期は物の豊かさが基準で世の中が動いて いたが, 今は, より精神的な豊かさを求める時代に 変化してきている。その結果, 自身の利益を追求し ていた時代から, みんなの利益のため社会の一員と して何が出来るか, という価值観への変化が見られ るように思う。

高度経済成長時代を走っていた時は，それぞれが 主役になった気持ちで過ごせた点, 幸せだったと思 う。世間では，これから団塊の世代が一斉に定年期 を迎える「2007年危機」が訪れると言われているが， 現実的には, 本当にその年歯層の労働力が急激に減 少するのは, 団塊世代が65歳を迎える2012年である と思う。確かに 2007 年以降, 社会的には大量の働き 手が第一線から退くかたちとなるが，この世代には 大きな男女の意識の差が見られる。博報堂・生活総 合研究所が実施した団塊世代への意識調査でも, 退 職する夫と妻の意識のズレが出ている。夫の $85 \%$ は， 定年後について「楽しみ」「ビジネスから離れ」「自 分の世界を第一に」「のんびり」という回答をしてい るが, 一方, 妻の $40 \%$ 「憂鬱」「出来ればビジネス に関わり」「外部との交流を第一に」「活動的」とい
うギャップが生じている。したがって, 兩者の意識 上のギャップの問題が現実味を帯びるのは，2007年 から2012年の間の過渡期であり，そこで大きく働く 人の意識が変わると思っている。

団塊の世代は常に, 世の中がこの大量の人数を抱 えた世代をどうするか, という社会問題を起こし, それをすべて克服してきた歴史がある。大きな人口 の塊が津波のように押し寄せて来ることに加えて, 都市部への人口の集中も追い討ちをかけ, まず学校 の不足が生じた。それに対して小学校の校舎が増築 され, 高校も新設され, 大学も新設・定員増加で対 応してきた。また住宅不足が社会現象になった時に は, 新たな住宅産業まで起こして住宅が整備され拡 大してきた。このような経済成長とともに歩んだ世 代の歴史は, 1980年代は30歳前半で企業の中でも右 肩上がりの経済成長の中, 必死に仕事に取り組み, 成果も出ていた時代である。1990年代に40代前半で 中間管理者の仲間入りをした時代は, 低成長, バブ ル崩壊と変化の激しい時期であった。いずれにして も20世紀は成長の歴史で右肩上がりの経済発展の時 代である。1990年以降, 女性の社会進出, 非婚化, 晚婚化が進み, 少子化が加速する。そして，2006年 で人口はピーク (1.27億人) になり，人口減少局面 に入ると言われている。このような時代の状況が, 知らず知らずのうちに働き手の意識の中にも着実に 変化を生み出していると思う。そして, 図1に示すよ うに, これからの人口構成の変化を見るにつけ, ゼ ネラルマネージャもシニアマネージャも実務担当者 も, 働く環境と意識の変化を考えざるを得ない状況 になっている。

情報管理の職場は, ベテラン技術者の活用と女性 情報専門家の活用が鍵になると思われるが，その背 景にある高歯化, 女性の社会進出, 少子化 (人口減 少）の中で, 働く人・働かせる人の意識の変化が現
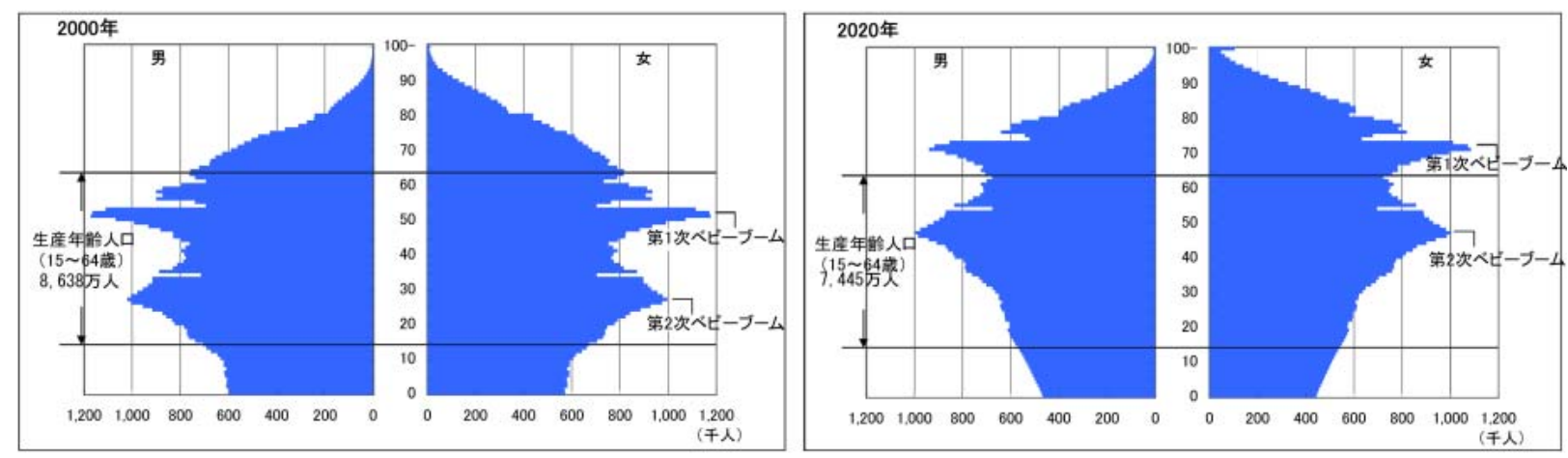

図12000年, 2020 年の生産年齢人口構成の変化 ${ }^{1)}$ 
れてきているように思う。このような状況で, 我々 団塊の世代が気を付けることは, 経済成長期の成功 体験が必ずしも成功につながらないということであ る。さまざまな社会環境が大きく変化していること を認識して，無理強いをしないことである。

\section{3. これから必要な「志」とは}

情報管理の現場も, 明らかに変曲点となっている。 企業にとって情報管理の業務がどれだけ問題解決に 答えられるのか, そのために必要な組織とはどうあ るべきなのかが閣われている。そこで最近,気になっ ている言葉が「志」である。一時は「志」だけでは 飯が食えないと言われた時代もあったが, 最近, 本 や雑誌でこの「志」という言葉をよく見かけるよう になった。というより自分で気になっている言葉だ から目に付くのかもしれない。

経営者に必要なのは「志」だと言われている。松 下幸之助氏の言葉にあるように,「電気製品が普及す るとみんな貧乏から救える」と考えた時から自社の あり方が変わった，それが松下流の「志」である。 そして, ヤマト運輸の小倉昌男氏の言葉にも「あの 宅急便を考えた時, 単なる一企業の事業でなく, 社 会的なインフラになるし, そうしたいと思った」と ある。また, 三菱商事社長の小島順彦氏も最近, 雑 誌のインタビューの中で,「リスクを負わなくなった のは「志」が無くなったせいで, それは教育（学校 でも家庭でも）をしなくなったためだ」と言われて いる。何をやれば有利か, 物事の損得での価值判断 だけでは「志」が不在である。特段な「志」を持た なくても右肩上がりの成長が実現される経済成長路 線の社会では, 個人的には「志」を持つ必要がなかっ たのかもしれない。だが, 日本の場合には高齢化の スピードが世界のトップランナーとも言われてい て，それに追い打ちをかけるように少子化（女性の 労働環境が未整備）が折り重なってくる状況では, 情報管理の現場でも「志」を持ってことに当たるこ とが必要な時代になると思う。

情報管理の現場では情報活用の時代に入り，現状 の延長線上の仕事だけでは対処できないと思う。情 報活用をするために何をしなければならないのか, 自分自身でテーマを持って考え, 考え抜くつもりで やらないと，情報はうまく的確に活用されない。情 報専門家自身が広く, 深く考えること, そしてそれ を継続することが大切である。なにも大きな「志」 だけではない，身の丈の「小志」「中志」があるはず である。「志」を持ってことに当たることで, 精神的 な安定にもつながり良い結果につながると思う。
これからの労働人口構成の変化を考えると, 情報 管理の現場では,

•さまざまな技術と経験を有するべテラン技術者 の活用

・従来から女性にも適した職域としてあった, 社 外の情報に詳しい情報専門家（サーチャーなど） や, 企業の場合には社内情報にも詳しい情報専 門家（ナレッジマネジメントなど）での女性人 材の積極的活用

・パソコンを使った業務が前提のITスキルを有す る専門家の活用

など, 多様な専門性が要求される職場となる。そ れぞれの立場, 持ち場で自分の位置付けを意識して, 背骨になるテーマを持ち, それぞれが「志」をもつ て当たることが大切である。依頼者からの依頼に対 応する受け身の情報提供サービス業務から脱皮し て, その人が本質的に欲しい情報を提供できるよう な情報活用・サービス業務へと発展していくために は, 自分自身が本質的に知りたい, 本質的な情報が 欲しい, そして知り得た情報の価值が判断できなけ ればならない, そういう「志」を持つことが必要で ある。

情報管理の現場では将来的には専門性の範囲が広 がり，若手・中堅・ベテラン（高龄者を含む）をう まく組み合せること, 男性・女性の区別なくそれぞ れの特性を生かすことでバランスの取れた職場とな るのが理想的である。そうなることで魅力ある職場 にできれば,「志」を持った, 新しい人材も飛び込ん できて, 情報管理の現場の活性化につながると考え ている。

\section{参考文献}

1）国立社会保障・人口問題研究所ホームページ。“人 ロピラミッドの推移” . (オンライン) , 入手先 $<$ http://www.ipss.go.jp/>, (参照2005-07-24) .

\section{木村 格 略歴}

東京造形大学造形学部デザイン学科卒業 1971年 三菱重工業(株)社長室, 開発部入社 1975年 同, 技術本部, 開発部 1986年 同，同，基盤技術研究所，研究企画推進室 1992年 同，同，同，管理課 課長 2000年10月より菱日エンジニアリング(株)技術情報部長 工業化住宅, 地域開発, バイオマスエネルギー等のプロ ジェクト開発に従事 (15年間), その後研究所での研究 企画と研究所運営管理に従事 (約 15 年間)。2001年 4 月 より三菱重工業(株)本社情報センター運営。 